\title{
STUDI PENENTUAN MUTU SUNGAI KELINGI LUBUKLINGGAU DENGAN METODE STORET DAN INDEKS PENCEMARAN
}

\author{
Akbar Mauli $^{1)}$, Agus Martono ${ }^{2)}$, Budiyanto ${ }^{3)}$ \\ ${ }^{1)}$ Dinas Lingkungan Hidup Kota Lubuklinggau \\ 2) Jurusan Kimia Fakultas MIPA UNIB \\ ${ }^{3)}$ Jurusan Teknologi Industri Fakultas Pertanian UNIB
}

\begin{abstract}
ABSTRAK
Sungai Kelingi diperkirakan telah mengalami tekanan dari lingkungan dan penurunan kualitas air, sehingga perlu dilakukan perhitungan dan mengidentifikasi kualitas Air Sungai. Pengambilan sampel dari hulu sampai kehilir Sungai Kelingi. Waktu penelitian dilaksanakan selama kurang lebih 4 bulan, dimulai dari bulan Januari sampai dengan April 2018. Hasil penelitian dan perhitungan status mutu air Sungai Kelingi yang telah dilakukan di 5 (lima) titik pengambilan sampel untuk 8 (delapan) parameter yaitu Suhu, TDS, TSS, pH, COD, BOD, Timbal dan Fecal Coliform yang dilaksanakan pada 08 Maret 2018 dapat disimpulkan bahwa; Status mutu air Sungai Kelingi jika di analisa dengan menggunakan metode STORET menunjukan bahwa Sungai Kelingi tergolong dalam kelas A (baik sekali) atau memenuhi baku mutu di semua titik pengambilan sampel. Pada perhitungan mengunakan metode Indeks Pencemaran (IP) menunjukan tercemar ringan pada titik 1,2 dan 5. Evaluasi status mutu air Sungai Kelingi dengan menggunakan metode Indeks Pencemaran (IP) tahun 2015 status mutu air Sungai Kelingi pada bagian hulu PIj sebesar 0,53 tergolong memenuhi baku mutu dan pada bagian hilir PIj sebesar 0,86 tergolong memenuhi baku mutu, tahun 2016 status mutu air Sungai Kelingi pada bagian hulu PIj sebesar 0,67 tergolong memenuhi baku mutu dan pada bagian hilir PIj sebesar 1,26 tergolong dalam cemar ringan, tahun 2017 status mutu air Sungai Kelingi pada bagian hulu PIj sebesar 1,31 tergolong dalam cemar ringan, pada bagian tengah PIj sebesar 1,59 tergolong dalam cemar ringan dan pada bagian hilir PIj sebesar 1,86 tergolong dalam cemar ringan.
\end{abstract}

Kata Kunci: Sungai, Kelingi, Kualitas Air, STORET dan Indeks Pencemaran

\section{PENDAHULUAN}

Sungai Kelingi merupakan sungai utama di Kota Lubuklinggau yang termasuk dalam Satuan Wilayah Pengelola (SWP) DAS Musi kedalam Sub DAS Kelingi dengan luas panjang sungai sekitar $70 \mathrm{~km}$. Wilayah Kota Lubuklinggau yang termasuk dalam Sub DAS Kelingi adalah Kecamatan Lubuklinggau Selatan I, Kecamatan Lubuklinggau Selatan II, Kecamatan Lubuklinggau Barat I, Kecamatan Lubuklinggau Barat II, Kecamatan Lubuklinggau Utara I, Kecamatan Lubuklinggau Utara II, Kecamatan Lubuklinggau Timur I,
Kecamatan Lubuklinggau Timur II (BPDAS Musi, 2014).

Aktivitas manusia yang ada di sepanjang Sungai Kelingi telah mempengaruhi kualitas air sungai. Aktivitas tersebut dapat berupa pertanian yang mengunakan pupuk dan pestisida di daerah hulu, pertambangan galian $\mathrm{C}$ baik di hulu, tengah dan hilir, limbah domestik dari penduduk dan aktivitas jasa dan industri yang ada di sepanjang Sungai Kelingi. Pencemaran sungai terjadi apabila kualitas air sungai turun sampai tingkat tertentu sehingga tidak dapat berfungsi sesuai dengan peruntukannya (PP 82 Tahun 2001 tentang Pengelolaan Kualitas 
Air dan Pengendalian Pencemaran Air). Berdasarkan hasil pemantuan kualitas air Sungai Kelingi yang dilakukan oleh Dinas Lingkungan Hidup Kota Lubuklinggau dari tahun 2015 sampai dengan 2017 ditemukan adanya parameter BOD yang melebihi baku mutu lingkungannya.

Dari uraian tersebut di atas, maka dapat dirumuskan permasalahan yang terindetifikasi dalam penelitian yaitu; Bagaimana kualitas air Sungai Kelingi saat ini jika dihitung dengan menggunakan metode STORET dan Indeks Pencemaran (IP)?. Bagaimana Perbandingan hasil perhitungan status mutu air sugai Kelingi dari tahun 2015, 2016, 2017 dan semester I tahun 2018.

Berdasarkan pendahuluan maka penulis dapat merumuskan tujuan penelitian untuk Mengklasifikasikan status mutu air Sungai Kelingi dengan menggunakan metode STORET dan Indeks Pencemaran (IP). Mengevaluasi status mutu air Sungai Kelingi dari tahun 2015, 2016, 2017 dan semester I tahun 2018 dengan menggunakan metode Indeks Pencemaran (IP).

\section{METODE PENELITIAN}

Tabel 1. Lokasi Titik Pengambilan Sampel

\begin{tabular}{|c|c|c|}
\hline \multirow[b]{2}{*}{ Lokasi Pengambilan Sampel } & \multicolumn{2}{|c|}{ Koordinat } \\
\hline & $\begin{array}{c}\text { Bujur Timur } \\
\text { (BT) }\end{array}$ & $\begin{array}{c}\text { Lintang Selatan } \\
\text { (LS) }\end{array}$ \\
\hline $\begin{array}{l}\text { Sungai Kelingi Bagian Hulu di Kelurahan Wa- } \\
\text { tas, Kecamatan Lubuklinggau Barat I Kota Lu- } \\
\text { buklinggau }\end{array}$ & $102^{\circ} 49^{\prime} 29,1^{\prime \prime}$ & $3^{\circ} 19^{\prime} 15,6^{\prime \prime}$ \\
\hline $\begin{array}{l}\text { Sungai Kelingi Bagian Tengah di Kelurahan Ja- } \\
\text { wa Kanan SS, Kecamatan Lubuklinggau Timur } \\
\text { II Kota Lubuklinggau }\end{array}$ & $102^{\circ} 52^{\prime} 05,4^{\prime \prime}$ & $3^{\circ} 17^{\prime} 22,3^{\prime \prime}$ \\
\hline $\begin{array}{l}\text { Sungai Kelingi Bagian Tengah di Kelurahan Ba- } \\
\text { tu Urip, Kecamatan Lubuklinggau Timur II Kota } \\
\text { Lubuklinggau }\end{array}$ & $102^{\circ} 52^{\prime} 43,1^{\prime \prime}$ & $3^{\circ} 17^{\prime} 10,9^{\prime \prime}$ \\
\hline $\begin{array}{l}\text { Sungai Kelingi Bagian Tengah di Kelurahan } \\
\text { Watervang, Kecamatan Lubuklinggau Timur II } \\
\text { Kota Lubuklinggau }\end{array}$ & $102^{\circ} 53^{\prime} 50,6^{\prime \prime}$ & $3^{\circ} 16^{\prime} 19,3^{\prime \prime}$ \\
\hline $\begin{array}{l}\text { Sungai Kelingi Bagian Hilir di Kelurahan Sim- } \\
\text { pang Periuk, Kecamatan Lubuklinggau Selatan I } \\
\text { Kota Lubuklinggau }\end{array}$ & $102^{\circ} 56^{\prime} 18,8^{\prime \prime}$ & $3^{\circ} 115^{\prime} 51,7^{\prime}$ \\
\hline
\end{tabular}

\section{Lokasi dan Waktu Penelitian}

Lokasi penelitian adalah di Sungai Kelingi Kota Lubuklinggau dengan melakukan pengambilan di 5 (lima) titik pengambilan sampel dari hulu sampai ke hilir Sungai Kelingi.

Waktu Penelitian.Waktu penelitian dilaksanakan selama 4 bulan, dimulai dari bulan Januari sampai dengan April 2018. Pengambilan sampel dilaksanakan pada tanggal 08 Maret 2018 dan analisa hasil dilaksanakan pada 08 -21 Maret 2018.

Pengujian parameter-parameter tersebut dilakukan dengan cara sebagai berikut : 1. Parameter Fisika: a). Suhu: Pengukuran suhu mengacu SNI 066898.23-2005 dengan menggunakan alat termometer air raksa, rnge $0-110^{\circ} \mathrm{c}, \mathrm{b}$ ). Daya Hantar Listrik: Pengukuran Daya Hantar Listrik mengacu pada SNI 066898.1-2004 dengan menggunakan alat konduktimeter., c). Padatan Terlarut (Total Dissolved Solid): Pengukuran padatan terlarut secara gravimetri mengacu pada SNI 06-6898.27- 2005, d). Padatan Tersuspensi (Total Suspended Solid): Pengukuran padatan tersuspensi secara gravimetri mengacu pada SNI 06-6898.32004. 
2. Parameter Kimia

a. $\mathrm{pH}$ : Pengukuran $\mathrm{pH}$ (derajat keasaman) mengacu pada SNI 06 6898.11-2004 dengan menggunakan $\mathrm{pH}$ meter.

b. COD: Pengukuran kebutuhan oksigen kimiawi dengan metode titrimetri mengacu pada SNI 06 6898.2-2009.

c. BOD: Pengukuran Kebutuhan Oksigen Biokimia mengacu pada SNI 06898.72-2009.

d. Timbal $(\mathrm{Pb})$ : Pengukuran logam Timbal $(\mathrm{Pb})$ mengacu pada SNI 6989.8-2009.

3. Parameter Mikrobiologi

Pada penelitian ini parameter mikrobiologi yang diukur adalah Fecal Coliform yang dianalisa dengan menggunakan metode APHA 9221 A-C.

\section{Tahap Penelitian}

1. Evaluasi Status Mutu Air Sungai Kelingi

Penetuan status mutu air Sungai Kelingi dilakukan dengan menggunakan metode STORET dan Indeks Pencemar (IP) berdasarkan PermenLH Nomor 115 Tahun 2003 tentang Penentuan Status Mutu Air, yaitu:

1. Metode STORET

2. Metode Indeks Pencemaran (IP)

2. Melaksanakan evaluasi pemantauan kualitas air Sungai Kelingi dari tahun 2015, 2016, 2017 dan Semester I 2018. Data hasil pemantauan akan diolah dengan menggunakan metode Indeks Pencemaran (IP), kemudian akan dilihat tren perubahan status mutu pada bagian hulu dan hilir Sungai Kelingi.

Melaksanakan evaluasi pemantauan kualitas air Sungai Kelingi dari tahun 2015, 2016, 2017 dan Semester I 2018. Data hasil pemantauan akan diolah dengan menggunakan metode Indeks Pencemaran (IP), kemudian akan dilihat tren perubahan status mutu pada bagian hulu dan hilir Sungai Kelingi.

\section{HASIL DAN PEMBAHASAN Identifikasi Karakteristik Kualitas Air Sungai Kelingi}

Kualitas air Sungai Kelingi dari 5 (lima ) titik pengambilan sampel diketahui berdasarkan pengukuran lapangan dan hasil pemeriksaan laboratorium untuk parameter fisika, kimia dan mikrobiologi. Pengambilan sampel dilakukan mulai pada pukul 09.00 WIB Pada tanggal 08 Maret 2018, musim hujan dengan volume air sungai sedang (kondisi normal). Hasil pemeriksaan laboratorium mengikuti ketentuan Peraturan Gubernur Nomor 16 Tahun 2005 tentang Peruntukan Air dan Baku Mutu Air Sungai pada Tabel 2.

\section{Perhitungan Status Mutu Air Sungai Kelingi}

a. Metode STORET

Hasil perhitungan status mutu air Sungai Kelingi dengan metode STORET ditampilkan pada Tabel 3.

b. Metode Indeks Pencemaran (IP)

Baku mutu yang digunakan mengacu kriteria mutu air sesuai kelas air pada Peraturan Gubernur Nomor 16 Tahun 2005 tentang Peruntukan Air dan Baku Mutu Air Sungai. Hasil perhitungan status mutu air Sunga Kelingi dengan metode indeks pencemaran di 5 (lima) titik lokasi pengambilan sampel disajikan pada Tabel 4.

Pada titik 3 dan titik 4 nilai Indeks Pencemaran (IP) kurang dari 1, menunjukan kualitas air Sungai Kelingi memenuhi baku mutu. Hal ini disebabkan sungai mempunyai kemampuan

memulihkan dirinya sendiri (self purification) dari bahan pencemar. Hal ini dapat di nilai dari nilai TDS yang memiliki nilai $152 \mathrm{mg} / \mathrm{L}$ pada titik 3 dan $142 \mathrm{mg} / \mathrm{L}$ pada titik 4 yang relatif lebih kecil titik pemantauan lain. Begitu juga dengan nilai $\mathrm{pH}$ dan fecal coliform yang memiliki nilai lebih kecil dari titik pemantuan lain. Ke- 
mampuan self purification sungai terjadi karena penambahan konsentrasi $\mathrm{O}_{2}$ terlarut dalam air yang berasal dari udara. Banyak- nya bebatuan yang besar menyebabkan terjadinya proses reaerasi.

\section{Tabel 2. Hasil analisa kualitas air Sungai Kelingi}

\begin{tabular}{|c|c|c|c|c|c|c|c|c|c|c|c|}
\hline \multirow{3}{*}{ Parameter } & \multirow{3}{*}{ Satuan } & \multicolumn{10}{|c|}{ Hasil Analisa kualitas air Sungai Kelingi } \\
\hline & & \multirow{2}{*}{$\begin{array}{l}\text { Titi } \\
\text { k } 1\end{array}$} & \multirow{2}{*}{$\begin{array}{c}\text { Kela } \\
\text { s }\end{array}$} & \multirow{2}{*}{$\begin{array}{c}\text { Titik } \\
2 \\
\end{array}$} & \multirow{2}{*}{\multicolumn{2}{|c|}{$\begin{array}{cc} & \text { Titik } \\
\text { Kelas } & 3 \\
\end{array}$}} & \multirow[b]{2}{*}{ Kelas } & \multirow{2}{*}{$\begin{array}{c}\text { Titik } \\
4\end{array}$} & \multirow{3}{*}{\multicolumn{2}{|c|}{$\begin{array}{c}\text { Titik } \\
5 \\
\end{array}$}} & \multirow[b]{2}{*}{ Kelas } \\
\hline & & & & & & & & & & & \\
\hline \multicolumn{10}{|l|}{ Fisika } & & \\
\hline Temperatur & ${ }^{\circ} \mathrm{C}$ & 24 & I & 25,5 & I & 26 & I & 25 & I & 29 & I \\
\hline TDS & $\mathrm{mg} / \mathrm{L}$ & 209 & I & 163 & I & 152 & I & 142 & I & 150 & I \\
\hline TSS & $\mathrm{mg} / \mathrm{L}$ & 14,2 & I & 17,8 & I & 15,8 & I & 15,1 & I & 13,1 & I \\
\hline \multicolumn{12}{|l|}{ Kimia } \\
\hline $\mathrm{pH}$ & Unit & 8,38 & I & 8,38 & I & 8,24 & I & 8,13 & I & 8,34 & I \\
\hline COD & $\mathrm{mg} / \mathrm{L}$ & 3,27 & I & 5,45 & I & 8,72 & I & 7,6 & I & 4,22 & I \\
\hline BOD & $\mathrm{mg} / \mathrm{L}$ & 0,9 & I & 0,7 & I & 1 & I & 1,6 & I & 1,4 & I \\
\hline $\begin{array}{l}\text { Timbal } \\
\text { Mikrobiologi }\end{array}$ & $\mathrm{mg} / \mathrm{L}$ & $\begin{array}{c}< \\
0,02\end{array}$ & I & $\stackrel{<}{0,02}$ & I & $\stackrel{<}{<, 02}$ & I & $\stackrel{<}{<, 02}$ & I & $\underset{0,02}{<}$ & I \\
\hline $\begin{array}{l}\text { Fecal } \\
\text { Coliform }\end{array}$ & $\begin{array}{c}\text { per } \\
100 \\
\text { ml }\end{array}$ & 39 & I & 75 & I & 43 & I & 20 & I & 75 & I \\
\hline
\end{tabular}

Tabel 3. Hasil Perhitungan Indeks Kualitas Air Sungai Kelingi Tahun 2018

\begin{tabular}{ccccc}
\hline Titik & Nilai & STORET & \multicolumn{2}{c}{ Indeks Pencemaran (IP) } \\
& 0 & Klasifikasi & Nilai & Klasifikasi \\
\hline Titik 1 & 0 & Memenuhi BML & $\mathbf{1 , 2 9}$ & Tercemar Ringan \\
Titik 2 & 0 & Memenuhi BML & $\mathbf{1 , 3 1}$ & Tercemar Ringan \\
Titik 3 & 0 & Memenuhi BML & $\mathbf{0 , 8 3}$ & Memenuhi BML \\
Titik 4 & 0 & Memenuhi BML & $\mathbf{0 , 6 4}$ & Memenuhi BML \\
Titik 5 & & & & Tercemar Ringan \\
\hline
\end{tabular}

Proses reaerasi merupakan proses penambahan kandungan $\mathrm{O}_{2}$ didalam air akibat turbulensi sehingga berlangsung difusi $\mathrm{O}_{2}$ dari udara ke air. Proses reaerasi dinyatakan dengan konstanta reaerasi yang tergantung pada kedalaman aliran, kecepatan aliran, kemiringan tepi sungai dan kekasaran dasar sungai (Keputusan Menteri Negara Lingkungan Hidup 115, 2003).

\section{Evaluasi Status Mutu Air Sungai Kelingi}

Evaluasi status mutu air Sungai Kelingi di lakukan dengan cara mengumpulkan data pemantuan kualitas air Sungai Kelingi dari tahun 2015 sampai dengan 2017. Kemudian, dilakukan pehitungan status mutu air Sungai Kelingi dengan menggunakan metode Indeks Pencemaran. Selanjutnya, dilakukan perbandingan dengan status mutu air Sungai Kelingi dengan perhitungan di tahun 2018. Data pemantuan kualitas air Sungai Kelingi seperti tampak dalam Tabel 4. 


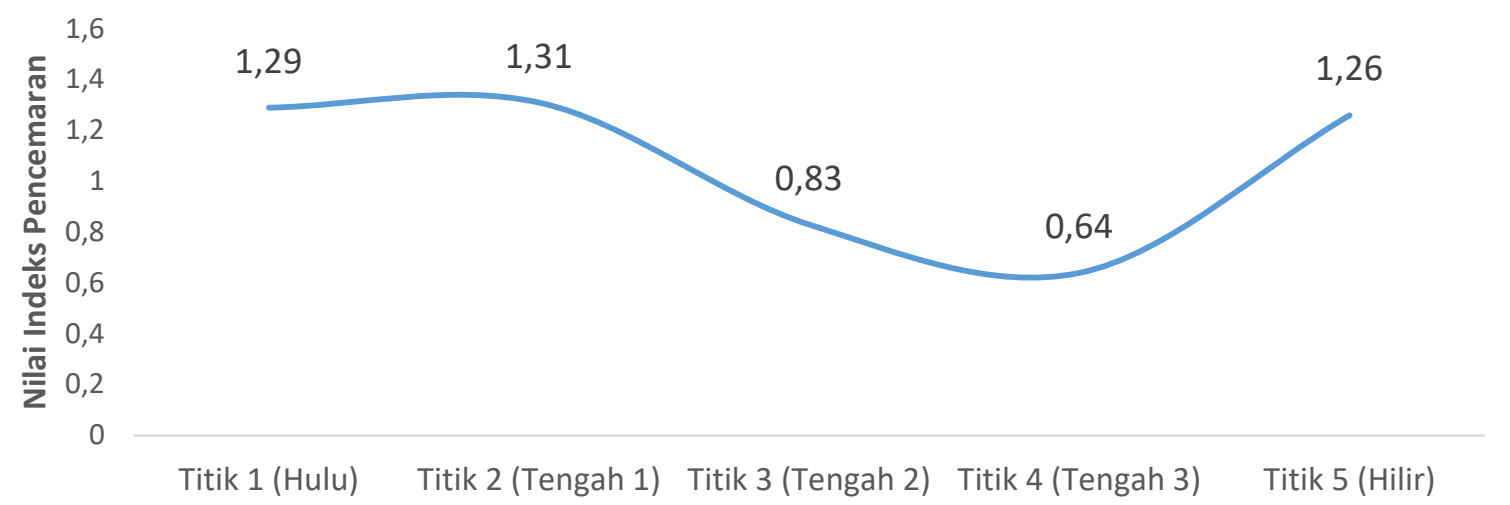

Nilai IP

\section{Gambar 1. Grafik Nilai Indeks Pencemaran Tahun 2018}

Tabel 4. Hasil Pemantauan Kualitas Air Sungai Kelingi Tahun 2015, 2016 dan 2017, dilakukan perhitungan status mutu airnya dengan menggunakan metode Indeks pencemaran. Hasil perhitungan status mutu air Sungai Kelingi untuk tahun 2015, 2016 dan 2017 tersaji pada Tabel 5. Tabel 5 di peroleh bahwa, pada tahun 2015 status mutu air Sungai Kelingi pada bagian hulu PIj sebesar 0,53 tergolong memenuhi baku mutu dan pada bagian hilir PIj sebesar 0,86 tergolong memenuhi baku mutu. Dari tabel 6. di dapat bahwa, pada tahun 2016 status mutu air Sungai Kelingi pada bagian hulu PIj sebesar 0,67 tergolong memenuhi baku mutu dan pada bagian hilir PIj sebesar 1,26 tergolong dalam cemar ringan. Dari Tabel 7. di dapat bahwa, pada tahun 2017 status mutu air Sungai Kelingi pada bagian hulu PIj sebesar 1,31 tergolong dalam cemar ringan, pada bagian tengah PIj sebesar 1,59 tergolong dalam cemar ringan dan pada bagian hilir PIj sebesar 1,86 tergolong dalam cemar ringan.

\section{Evaluasi kualitas air Sungai Kelingi Bagian Hulu}

Distribusi kondisi status mutu air Sungai Kelingi berdasarkan Indeks Pencemaran (IP) dari tahun 2015 sampai dengan tahun 2018 pada bagian hulu di tampilkan dalam Gambar 2.

Gambar 2 dapat dilihat terjadi kenaikan nilai IP pada bagian hulu Sungai Kelingi dari tahun 2015 sampai dengan tahun 2018. Hal ini di karenakan aktivitas pada bagian hulu yang di sebabkan alih fungsi lahan hutan menjadi lahan pertanian, aktivitas galian $\mathrm{C}$ dan pertambahan jumlah penduduk. Kenaikan nilai IP di sebabkan oleh kenaikan parameter TSS, COD, BOD dan Fecal Coliform. Walaupun kenaikannya tidak signifikan, akan tetapi secara akumulasi meningkatkan nilai Indeks Pencemaran (IP) secara keseluruhan.

Trend status mutu air Sungai Kelingi pada bagian hulu dari tahun 2015, 2016, 2017 dan 2018 pada setiap parameter disajikan dalam Gambar 3. 
Tabel 4. Hasil Pemantauan Kualitas Air Sungai Kelingi Tahun 2015, 2016 dan 2017

\begin{tabular}{|c|c|c|c|c|c|c|c|c|c|}
\hline \multirow{3}{*}{ Parameter } & \multirow{3}{*}{ Satuan } & \multirow{3}{*}{ BML } & \multicolumn{7}{|c|}{ Hasil Analisa kualitas air Sungai Kelingi } \\
\hline & & & \multicolumn{2}{|c|}{2015} & \multicolumn{2}{|c|}{2016} & \multicolumn{3}{|c|}{2017} \\
\hline & & & Hulu & Hilir & Hulu & Hilir & Hulu & Tengah & Hilir \\
\hline \multicolumn{10}{|l|}{ Fisika } \\
\hline Temperatur & ${ }^{\circ} \mathrm{C}$ & $\begin{array}{l}\text { Devias } \\
\text { i } 3\end{array}$ & 29 & 28 & 25 & 27 & 26 & 28 & 27,5 \\
\hline TDS & $\mathrm{mg} / \mathrm{L}$ & 1000 & 231 & 181 & 231 & 182 & 64,9 & 47,9 & 46,3 \\
\hline TSS & $\mathrm{mg} / \mathrm{L}$ & 50 & 4,2 & 53 & 3,89 & 2,78 & 53,4 & 52,6 & 48,5 \\
\hline \multicolumn{10}{|l|}{ Kimia } \\
\hline $\mathrm{pH}$ & Unit & $\begin{array}{l}6,0 \\
9,0\end{array}$ & 6 & 6 & 7,8 & 7,4 & 7,68 & 7,28 & 7,55 \\
\hline COD & $\mathrm{mg} / \mathrm{L}$ & 10 & 7,06 & 8,09 & 7,01 & 13,6 & 13,9 & 16,3 & 19,3 \\
\hline BOD & $\mathrm{mg} / \mathrm{L}$ & 2 & 1,28 & 1,42 & 1,67 & 2,14 & 1,79 & 2,11 & 2,35 \\
\hline $\begin{array}{l}\text { Timbal } \\
\text { Mikrobiolog } \\
\text { i }\end{array}$ & $\mathrm{mg} / \mathrm{L}$ & 0,3 & - & - & $\begin{array}{l}0,04 \\
8\end{array}$ & $\begin{array}{l}0,04 \\
5\end{array}$ & $\begin{array}{l}<0,04 \\
9\end{array}$ & $\begin{array}{l}<0,04 \\
9\end{array}$ & $\begin{array}{l}<0,04 \\
9\end{array}$ \\
\hline $\begin{array}{l}\text { Fecal } \\
\text { Coliform }\end{array}$ & $\begin{array}{ll}\text { per } & 100 \\
\text { ml }\end{array}$ & 100 & $\begin{array}{l}\text { negati } \\
\text { f }\end{array}$ & $\begin{array}{l}\text { negati } \\
\text { f }\end{array}$ & - & - & $\begin{array}{l}\text { negati } \\
\text { f }\end{array}$ & 100 & 100 \\
\hline
\end{tabular}

Sumber: SLHD Kota Lubuklinggau, 2015-2017

Tabel 5. Hasil Perhitungan Indeks Kualitas Air Sungai Kelingi Tahun 2015, 2016, 2017,

\begin{tabular}{|c|c|c|c|c|c|c|c|c|}
\hline \multirow{2}{*}{ Titik } & \multicolumn{2}{|c|}{2015} & \multicolumn{2}{|c|}{2016} & \multicolumn{2}{|c|}{2017} & \multicolumn{2}{|c|}{2018} \\
\hline & Nilai IP & Klasifikasi & Nilai IP & Klasifikasi & Nilai IP & Klasifikasi & Nilai IP & Klasifikasi \\
\hline Titik 1 & 0,53 & $\begin{array}{l}\text { Memenuhi } \\
\text { BM }\end{array}$ & 0,67 & $\begin{array}{l}\text { Memenuhi } \\
\text { BM }\end{array}$ & 1,31 & $\begin{array}{c}\text { Tercemar } \\
\text { Ringan }\end{array}$ & 1,29 & $\begin{array}{c}\text { Tercemar } \\
\text { Ringan }\end{array}$ \\
\hline Titik 2 & & & & & 1,59 & $\begin{array}{c}\text { Tercemar } \\
\text { Ringan }\end{array}$ & 1,31 & $\begin{array}{c}\text { Tercemar } \\
\text { Ringan }\end{array}$ \\
\hline Titik 3 & & & & & & & 0,83 & $\begin{array}{l}\text { Memenuhi } \\
\text { BM }\end{array}$ \\
\hline Titik 4 & & & & & & & 0,64 & $\begin{array}{l}\text { Memenuhi } \\
\text { BM }\end{array}$ \\
\hline Titik 5 & 0,86 & $\begin{array}{l}\text { Memenuhi } \\
\text { BM }\end{array}$ & 1,26 & $\begin{array}{c}\text { Tercemar } \\
\text { Ringan }\end{array}$ & 1,86 & $\begin{array}{c}\text { Tercemar } \\
\text { Ringan }\end{array}$ & 1,26 & $\begin{array}{c}\text { Tercemar } \\
\text { Ringan }\end{array}$ \\
\hline
\end{tabular}

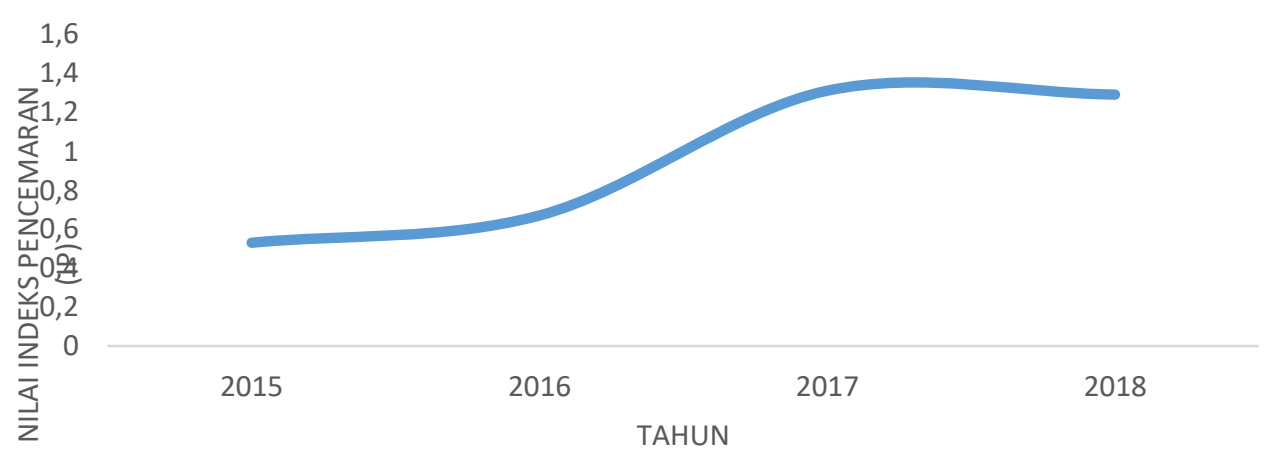

Gambar 2. Grafik Evaluasi Nilai Indeks Pencemaran Bagian Hulu 


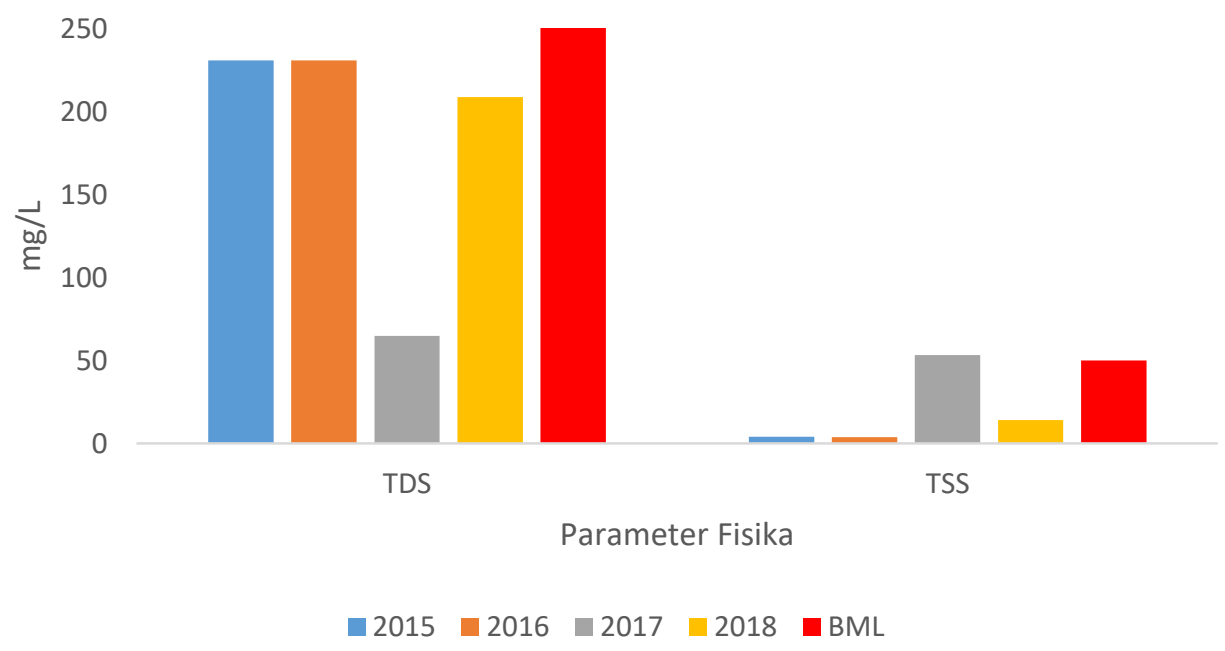

Gambar 3. Grafik Trend status mutu Air Sungai Kelingi bagian hulu parameter fisika.

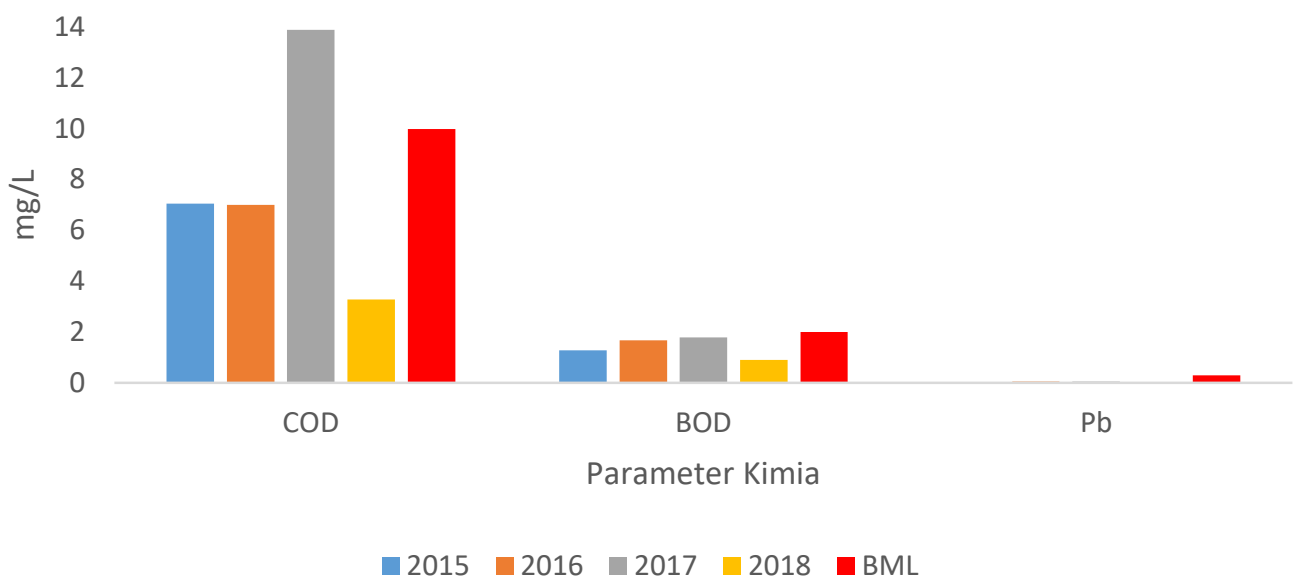

Gambar 4. Grafik Trend status mutu Air Sungai Kelingi bagian hulu parameter kimia.

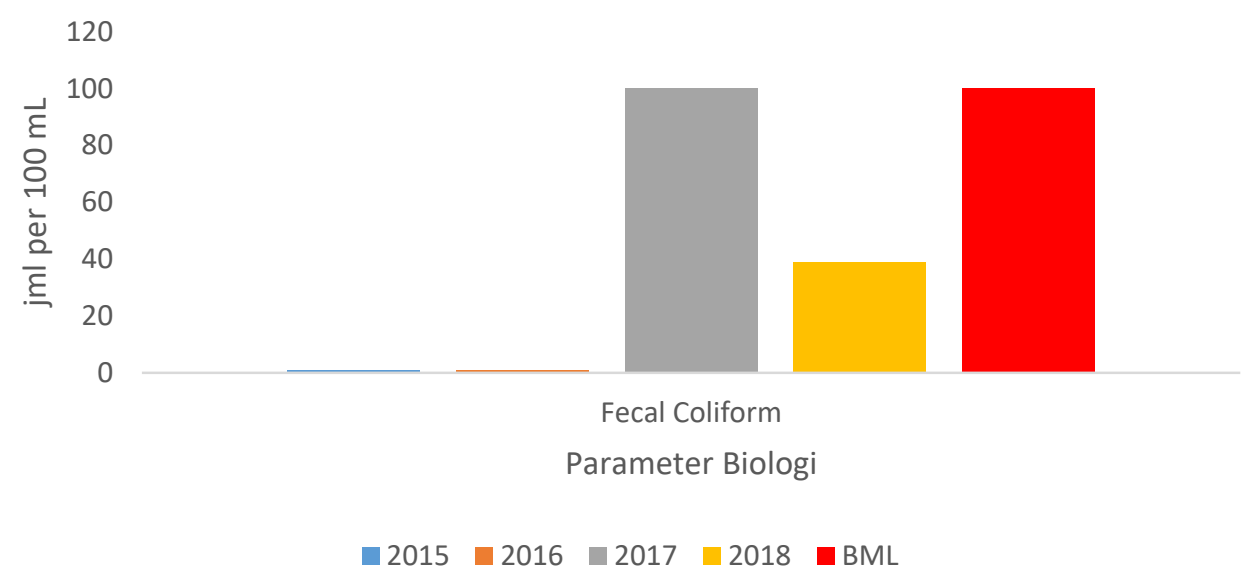

Gambar 5. Grafik Trend status mutu Air Sungai Kelingi bagian hulu parameter biologi. 


\section{Evaluasi kualitas air Sungai Kelingi Bagian Hilir}

Distribusi kondisi status mutu air Sungai Kelingi berdasarkan Indeks
Pencemaran (IP) dari tahun 2015 sampai dengan tahun 2018 pada bagian hilir di tampilkan dalam Gambar 6.

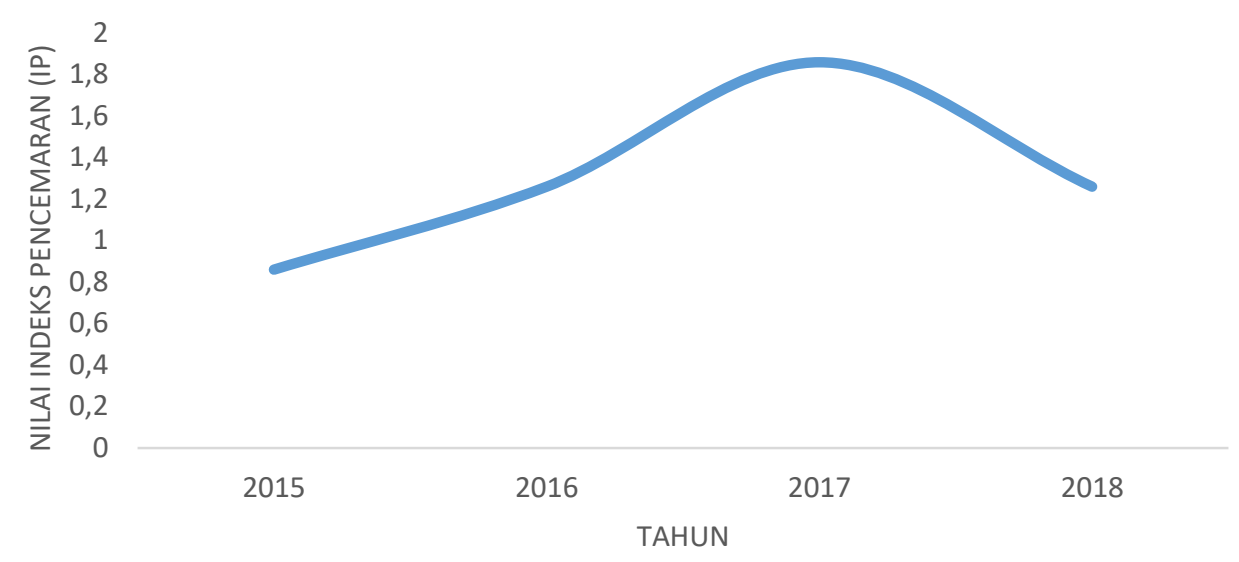

Gambar 6. Grafik Evaluasi Nilai Indeks Pencemaran Bagian Hilir

Gambar 6 dapat dilihat terjadi kenaikan nilai IP pada bagian hilir Sungai Kelingi dari tahun 2015 sampai dengan tahun 2018. Hal ini di karenakan aktivitas pada bagian hilir yang di sebabkan pertambahan jumlah penduduk, permukiman dan aktivitas industri dan jasa. Kenaikan nilai IP di sebabkan oleh kenaikan parameter COD, BOD dan Fecal Coliform. Walaupun kenaikannya tidak signifikan, akan tetapi secara akumulasi meningkatkan nilai Indeks Pencemaran (IP) secara keseluruhan.

Trend status mutu air Sungai Kelingi pada bagian hilir dari tahun 2015, 2016, 2017 dan 2018 pada setiap parameter disajikan dalam Gambar 7, Gambar 8 dan Gambar 9.

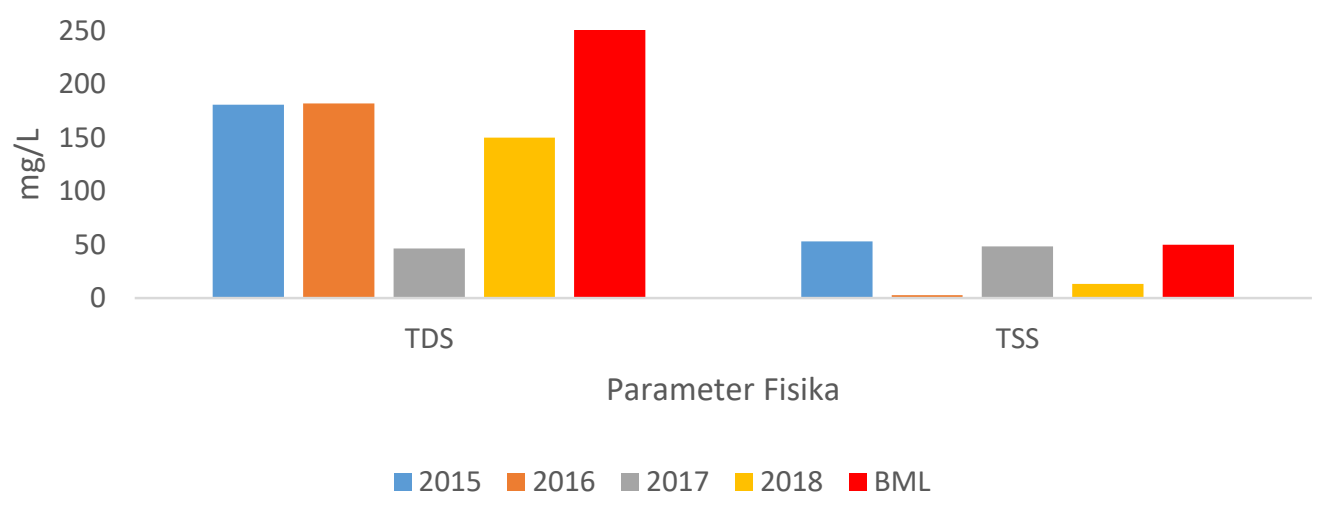

Gambar 7. Grafik Trend status mutu Air Sungai Kelingi bagian hilir parameter fisika. 


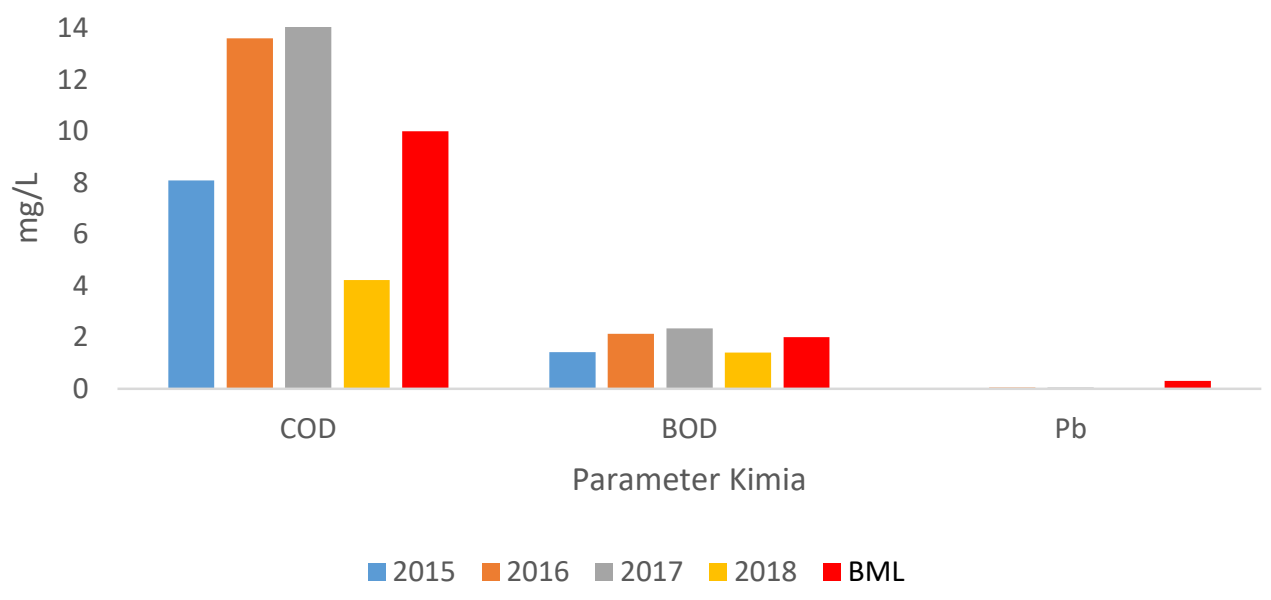

Gambar 8. Grafik Trend status mutu Air Sungai Kelingi bagian hilir parameter kimia.

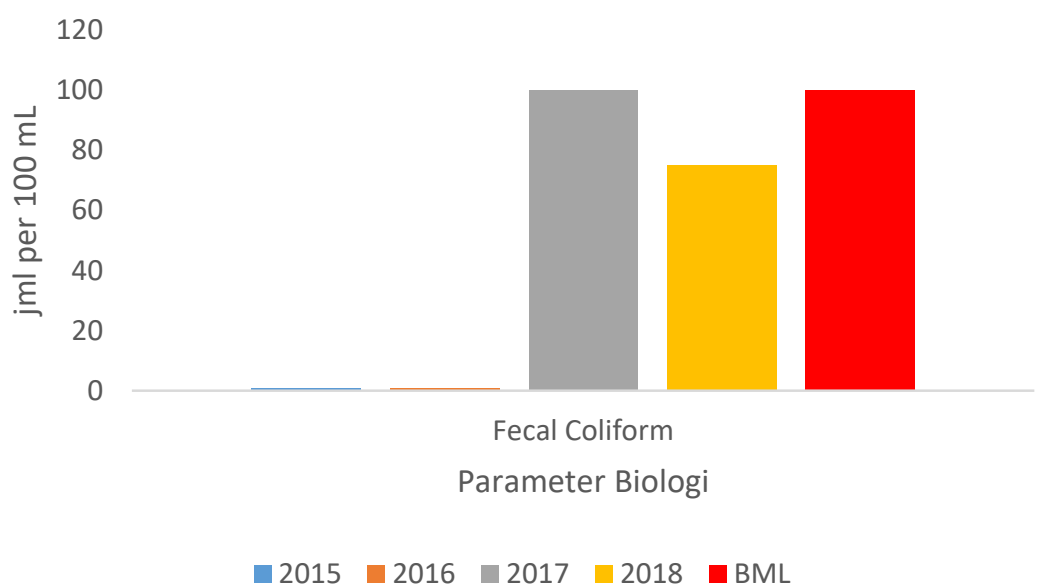

Gambar 9. Grafik Trend status mutu Air Sungai Kelingi bagian hilir parameter biologi.

\section{KESIMPULAN}

Berdasarkan hasil penelitian dan perhitungan status mutu air Sungai Kelingi yang telah dilakukan di 5 (lima) titik pengambilan sampel untuk 8 (delapan) parameter yaitu Suhu, TDS, TSS, pH, COD, BOD, Timbal dan Fecal Coliform yang dilaksanakan pada 08 Maret 2018 dapat disimpulkan bahwa:

Status mutu air Sungai Kelingi jika dianalisa dengan menggunakan metode STORET menunjukan bahwa Sungai
Kelingi tergolong dalam kelas A (baik sekali) atau memenuhi baku mutu di semua titik pengambilan sampel. Pada perhitungan mengunakan metode Indeks Pencemaran (IP) menunjukan tercemar ringan pada titik 1,2 dan 5 .

Evaluasi status mutu air Sungai Kelingi dengan menggunakan metode Indeks Pencemaran (IP) tahun 2015 status mutu air Sungai Kelingi pada bagian hulu PIj sebesar 0,53 tergolong memenuhi baku mutu dan pada bagian hilir PIj sebesar 0,86 tergolong memenuhi baku mutu, tahun 
2016 status mutu air Sungai Kelingi pada bagian hulu PIj sebesar 0,67 tergolong memenuhi baku mutu dan pada bagian hilir PIj sebesar 1,26 tergolong dalam cemar ringan, tahun 2017 status mutu air Sungai Kelingi pada bagian hulu PIj sebesar 1,31 tergolong dalam cemar ringan, pada bagian tengah PIj sebesar 1,59 tergolong dalam cemar ringan dan pada bagian hilir PIj sebesar 1,86 tergolong dalam cemar ringan.

\section{DAFTAR PUSTAKA}

Asdak, C. 2010. Hidrologi dan Pengelolaan Daerah Aliran Sungai. Gajah Mada University Press. Yogyakarta.

Badan Pusat Statistik Kota Lubuklinggau. 2017. Kota Lubuklinggau Dalam Angka 2017. www.bps.go.id

Badan Standardisasi Nasional. SNI 066989.11-2004. Air dan Air Limbah Bagian 11 : Cara Uji Derajat Keasaman $(\mathrm{pH})$ dengan Menggunakan alat $\mathrm{pH}$ Meter.

Badan Standardisasi Nasional. SNI 6989.82009. Air dan Air Limbah - Bagian 8 : Cara Uji Kebutuhan Timbal $(\mathrm{Pb})$.

Davis, M. L. and D. A. Cornwell. 1991. Introduction to Environmental
Engineering. Second Edition. McGraw-Hill. Inc, New York.

Dinas Lingkungan Hidup Kota Lubuklinggau. 2017. Status Lingkungan Hidup Daerah (SLHD) Kota Lubukinggau 2017. www.klh.lubuklinggaukota.go.id

Hach, C. C. R. L. Klein, Jr. C. R. Gibbs. 1997. Introduction to Biochemical Oxygen demand. Technival Information Series. No. 7. Hach Company.

USA.

Peraturan Pemerintah Nomor 38 Tahun 2011 tentang Sungai.

Peraturan Pemerintah Nomor 82 Tahun 2001 tentang Pengelolaan Kualitas Air dan Pengendalian Pencemaran Air.

Rukaesih, A. 2004. Kimia Lingkungan. Penerbit Andi. Yogyakarta.

Suriawiria, U. 2003. Air dalam Kehidupan dan Lingkungan yang Sehat. Penerbit Alumni. Bandung.

Wardhana, W. 2004. Dampak Pencemaran Lingkungan. Penerbit ANDI. Yogyakarta.

Wiwoho. 2005. Model Identifikasi Daya Tampung Beban Cemaran Sungai Dengan QUAL2E. Tesis. Universitas Diponegoro. Semarang 